\title{
Practices of Historicism in Times of Change: Chaucer, Pope, Barron Field, A. D. Hope and the Idea of the Culture Hero
}

\section{A. D. Cousins}

Macquarie University, Australia

Corresponding Author:

A. D. Cousins

tony.cousins@mq.edu.au

Received: 1 July 2019

Accepted: 18 July 2019

Published: 31 July 2019

Publishing services provided by

Knowledge

(c) A. D. Cousins. This article is distributed under the terms of the Creative Commons.

Attribution License, which permits unrestricted use and redistribution provided that the original author and source are credited.

Selection and Peer-review unde the responsibility of the AICLL 2019 Conference Committee.
Myths of cultural heroism are transhistorical, transnational and transcultural. Repeatedly, although not exclusively, they centre upon figures who are either primal civilizers of humankind itself-for example, Prometheus-or founders of particular civilizations, such as Aeneas. Yet those familiar Graeco-Roman archetypes, Prometheus and Aeneas, remind us that portrayals of culture heroes have tended, from the very beginnings of Western literature, to dramatize personae who are at once heroic and flawed. The culture heroes of the West are often problematic. Sometimes, they are self-divided; they may even be disconcertingly paradoxical. In them, we are shown interplay between creativity and destructiveness-whether that creativity be used for the benefit of all humankind or for the good of a specific social group; whether that destructiveness be visited upon others, the culture heroes themselves, or both.

By way of illustration, one has merely to glance at representations of the two heroes just now mentioned. The first, Prometheus, is depicted variously-as we would expectby Hesiod, Aeschylus and Plato but he nonetheless appears across their quite different texts with iterated characteristics. He plays out the roles of trickster, of magnanimously self-destructive rebel, of humankind's primal civilizer [1]. Just so, Aeneas, who is destined to be the founder of that New Troy which will become Rome and the seat of empire, performs the roles of dutiful son, dutiful husband, dutiful father, and dutiful champion of his devastated community. Yet this embodiment of duty-pius Aeneas-is also the lover of Dido. He is her undutiful lover-hence, impius-inasmuch as his unsanctioned love for her betrays the best interests of his people and ends with betrayal of her total trust in him [2]. From the outset, Western myths of cultural heroism have tended to be shaped by radical antithesis.

My aim here is not, however, simply to emphasize the discord embedded in occidental conceptualizing of the culture hero. I want rather to suggest a couple of its significances. First, I want to propose that the self-contradictoriness to which I have been drawing S OPEN ACCESS attention in the protagonists of originary or foundational myths is indicative of a larger 
instability, a latent incoherence diversely recurrent across Western myths of cultural heroism throughout both older and recent literatures in English. Second, I want to propose as well that perceiving the idea of the culture hero from this historicist perspective enables us to appreciate ways in which, via current uses of social media, the idea of the culture hero-configuration of the culture hero-has been consciously or otherwise appropriated in the West and perhaps at times unwittingly if nevertheless subversively reconstituted.

I shall begin, then, by exploring the doubleness, which is likewise to say, the ambiguity intrinsic to so many Western incarnations of the civilizing hero and formulations of originary fictions. An apt starting place is with Geoffrey Chaucer, whom John Dryden would influentially identify as 'the father of English poetry', and in particular with his House of Fame [3]. There, when exploring the duplicities of Fama (which is inherently double, being both rumour and renown), Chaucer has his persona scrutinize the bifurcated characterization of Aeneas in Aeneid 4 [4]. He bases his scrutiny of Aeneas primarily of course on the hero's portrayal by Virgil, but clearly signals too that he is aware of the lore that has subsequently accumulated around the Aeneid's protagonist [5]. The Chaucerian speaker alludes to the dutifulness (pietas) of Aeneas (143-8) [6]. He also tells how the prince of Troy carried his father (who clutched their domestic gods) to safety from the destruction of their city (166-73). Nevertheless, the speaker likewise proceeds to recount Aeneas' undutiful response to Dido's devotion: 'For he to hir a traytour was; / Wherfore she slow hirself, allas!' (267-8). And he later continues: 'But let us speke of Eneas, / How he betrayed hir [Dido], allas, / And lefte hir ful unkyndely' (293-5). He represents Aeneas, then, as both pius and impius-as the dutiful demigod yet, at the same time, someone connected to Sinon. Through the latter's 'false forswerynge', Chaucer's speaker had earlier remarked, Troy fell and the 'Troyens loste al her joye' (1516). The speaker subsequently notes that Virgil's text clears Aeneas of guilt, but seems himself less than convinced of the absolution's persuasiveness (427-32). Moreover, prior to that the speaker had offered a long survey of heroic treacheries to women: a striking list of negative exemplars (383-426).

Just as Aeneas (even if at first unwittingly) captures Dido and himself becomes caught in the contradictions of desire, so he is inescapably linked with her to the doubleness of Fama. That doubleness extends of course beyond a simple antithesis between renown and rumour. According to the Chaucerian persona's insight into what he sees before him, although Virgil's Aeneid and the mural derived from it in the Temple each show the renown of Aeneas, each celebrates a heroic stature that is contaminated by treachery. 
They confer on Aeneas a substantial renown marked by infamy; and he, for his part, helps to make Dido subject to the misery of hostile rumour. At the close of and climax to the complaint she voices in response to her betrayal by Aeneas, Dido exclaims:

"O wel-awey that I was born!

For thorgh yow is my name lorn,

And all myn actes red and songe

Over al thys lond, on every tonge.

O wikke Fame!-for ther nys

Nothing so swift, lo, as she is!" (345-50)

Against the power of Fama-as-ill-repute, remarks the Chaucerian speaker: 'Al hir compleynt ne al hir moone, / Certeyn, avayleth hir not a stre' (362-3). Yet in the Ovidian model for Dido's lament (Heroides 7, towards which the speaker gestures at 379-80), Dido both acknowledges that she has become the victim of rumour and implies that Aeneas, should he survive, will as well [7]. Chaucer's speaker makes that happen.

What 'the father of English poetry' suggests through that interpretation of Aeneas is this. The most prominent, the greatest of the West's originary heroes embodies a selfcontradiction-a self-division-that implicitly subverts the most important foundation myth in Western culture (namely, the tale of renovatio, of trans/atio imperii et studii). The imperative to interrogate that political narrative will thereafter likewise repeatedly confront occidental poets concerned with the idea of cultural heroism.

So we see distinctly in The Temple of Fame, Alexander Pope's refashioning of Chaucer's poem in the reign of Queen Anne [8]. From Chaucer's poem, as it happens, Pope inherits two issues. First, of course, how to deal with the ambiguous figure of Aeneas; but also, second, how to deal with the problems created by Virgil's-and, thence, Chaucer's-characterization of Aeneas for those poets who would themselves aspire to the role of culture hero via celebrating originary heroes of legend. Pope's response to the first of those issues is both simple and revealing. He ignores problems intrinsic to the characterization of Aeneas, alluding to the Troy myth quite briefly (18895, 205-9). His response to the second issue is no less simple and decisive. Chaucer, who would at least notionally become 'the father of English poetry', had in his House of Fame identified Homer-by tradition called 'the father of Western poetry'-as a perhaps unreliable source, a writer of uncertain authority (1464-80). Pope presents Homer as the unquestionable founder of Western verse: implicitly, as a torch-bearer of civilization (182-95). That is to say, when confronted by the inconsistencies elemental to the West's 
central mythos of national beginnings, Pope responds with silent evasion. He occludes those challenges because they are inconvenient to his purpose and, in any case, beyond resolution. Yet it is not only poets from the English past, and re-creating the story of Aeneas, who have struggled to achieve conceptual stability and coherence as they sought to fashion icons of cultural heroism.

Soon after the European settlement of Australia, the unfortunately named Barron Field published his First Fruits of Australian Poetry (1819). This was not by any means the first verse to have been printed in the new colony-as Field would have been aware. However, his title seems to indicate that the volume displays his own, initial poetic harvest and, moreover, that no genuine Australian verse had in fact preceded his own. I have argued elsewhere that Field's volume implies the impossibility of bringing a Wordsworthian version of Romanticism to Terra Australis and thus, in so very particular a sense, negates the trans/atio studii topos [9]. Here I am more concerned with how, in the poems later added to those of the first volume (1823), Field confronts the impossibility of aligning Australia's colonization with the idea of cultural heroism.

An unavoidable predicament for Field is that, from a European perspective, the antipodean New World has no history. In 'On Reading the Controversy between Lord Byron and Mr Bowles', at lines 5-7 his persona calls Australia, 'A land without antiquities, with one, / And only one, poor spot of classic ground, / (That on which Cook first landed)' [10]. He continues: 'Where's no past tense, the ign'rant present's all; / Or only great by the All hail, hereafter!' (14-15). As a consequence, when addressing this quandary, Field proposes a solution to it with what seems almost desperation and is, at the least, unease. His pair of sonnets celebrating Captain James Cook and Sir Joseph Banks' arrival at Botany Bay make that unmistakably clear.

Field uses the phrase 'classic ground' again at the close to the first of those paired poems. Thereby his speaker emphatically concludes a narrative in which Cook's landing is commemorated as a truly foundational moment: an act of political and, more important, religious beginnings (9-12). The attempt throughout that initial sonnet to constellate not a tale of discovery but a foundation myth around Cook and Banks-particularly around the former-is nevertheless self-consciously precarious. Field's use of the phrase 'classic ground' intimates as much, of course. In his 'Controversy' poem, the speaker's wry or perhaps satirical articulation of the phrase ('only one, poor spot of classic ground', 6) stresses the all but total emptiness notionally confronting anyone who seeks to mythologize Australia's settlement by Europeans-to fashion a mythos of origins. What further problematizes the triumphalist story unfolded in this sonnet is how Field's persona characterizes Cook himself. In the poem's second verse, Cook is proclaimed 
'our Columbus of the South'. Equating Cook with an earlier and more famous New World hero, Field's speaker seeks to link Australia with a tradition of Western expansionism, on the one hand and, on the other, with America. Yet the bold assertion blends two utterly different people in quite disparate circumstances-and Field seems not, in any case, to have liked America ('Controversy', 11-12). His conclusion to the accompanying sonnet is arguably still more self-conflicted [11].

Just over a century later (1939), A. D. Hope expresses a similar albeit also antithetic apprehension of European Australia in a poem bearing his country's name. There he describes his homeland as being, 'Without songs, architecture, history: / The emotions and superstitions of younger lands' (9-10) [12]. Australia is presented not as a newly Europeanised, and therefore 'young' country, but as a continent too ancient, too barren, for truly productive European habitation. This is a country Europeans can occupy but cannot possess (5-16). It is therefore no surprise that, according to Hope's persona, nothing like Field's vision of trans/atio imperii et studii to the Great South Land has been realized. Indeed, we are led to infer, even now (namely, in the mid-twentieth century) colonial modernity has failed to set a European impress upon the ancient continent (17-20). Hope's speaker is however simultaneously of the view that, in Europe itself, modernity has failed-generating not enlightenment of spirit but rather 'the lush jungle of modern thought' (22).

Perhaps, then, Hope has his persona hypothesize, from the open and at least clear mental space inherent to the ancient emptiness which is Australia-as it were, an 'Arabian desert of the human mind', (23)-may emerge 'some spirit which escapes / The learned doubt, the chatter of cultured apes / Which is called civilization over there' (26-28). He hypothesizes the advent of a cultural prophet from that desert, "if still from the deserts the prophets come' in these latter-day times (24). Hope's uncertain anticipation that cultural heroism may, at some indeterminate time, epiphanically manifest itself in the antipodes implies the ambiguity with which he evokes the idea of the culture hero. Certainly, it reveals him to be wary of casting himself as a culture hero: even more hesitant to assume such a role than was Field. Throughout 'Australia' he has his persona enact the role, rather, of Juvenalian anti-hero.

That said, the question arises, 'what can intellectual history-when brought to bear upon the idea of the culture hero-help us to see more clearly within contemporary societies as they start to make their ways through Industrial Revolution 4.0?' It allows us, I suggest, to see quite distinctly that amidst the radical reorganization of our societies, especially but not solely in the West, we are creating semblances of meaning, value, and 
control by the generation of culture heroes across social media within the now-global celebrity culture-and, at the same time, that we are for the most part unaware of (or indifferent to) participating in a problematic tradition as we do so. This is a significant phenomenon in nation states (such as Australia) that lack effective mythologies of their own beginnings. But it is as well in nation states (such as America) that have established foundational mythologies. Particularly in the latter case, one conjectures, if those mythologies have been subjected over time to demythologizing scrutiny. Social media, and the celebrity culture no less enhanced than served by it, offer people opportunity to stage possession of an originary function or foundational vision: the opportunity to assume roles as culture heroes. Some of these people, as we know, are insistent in magnifying their claims to cultural heroism. Some others actually have power but, when participating in celebrity culture through social media, choose neither to understand it nor to exercise the moral responsibility that should accompany it. Preoccupied with the ephemeral and the fantasy of an illimitable selfhood they act, one could say, without awareness of (or, again, without caring about) how the past illuminates their aspirations and our susceptibility to them.

\section{References}

[1] For an instance in little, see Hesiod, Theogony 483-585 in Works of Hesiod and The Homeric Hymns, trans. Daryl Hine (Chicago: University of Chicago Press, 2005)

[2] Contrast Aeneid 2, 701-29 with 4, 296-330 in Virgil, Eclogues, Georgics and Aeneid 1-6, ed. and trans. H. Rushton Fairclough, rev. G. P. Goold, Loeb Classical Library (1999; rpt. Cambridge: Harvard University Press,2006)

[3] John Dryden, 'Preface to Fables Ancient and Modern', in idem, Of Dramatic Poesy and Other Critical Essays, ed. and introd. George Watson, 2 vols (London: Dent and Sons, 1962), vol. 2, 280

[4] On the discourse of fame, see: Leo Braudy, The Frenzy of Renown: Fame and Its History (New York: Oxford University Press, 1986); Philip Hardie, Rumour and Renown: Representations of Fama in Western Literature (Cambridge: Cambridge University Press, 2012); Antoine Lilti, The Invention of Celebrity, trans. Lynn Jeffress (Cambridge: Polity Press, 2017)

[5] Here, and in what immediately follows, I am drawing on material from my chapter, 'Pope and Chaucer: Reconstructing The House of Fame in the Reign of Queen Anne', to appear in Alexander Pope in the Reign of Queen Anne: Reconsiderations of His Early Career, eds A. D. Cousins and Daniel Derrin (forthcoming through Routledge) 
[6] Reference to The House of Fame comes from The Riverside Chaucer, gen. ed. Larry D. Benson, 3rd edn (Boston: Houghton Mifflin Company, 1987), 347-73

[7] Ovid, Heroides 7, at 5-6 and 63-4 in Heroides and Amores, ed. and trans. Grant Showerman, Loeb Classical Library (1921; rpt. Cambridge, MA: Harvard University Press, 1947)

[8] Reference to The Temple of Fame is from Alexander Pope, The Rape of the Lock and Other Poems, ed. Geoffrey Tillotson, 3rd edn (1960; rpt. London: Methuen, 1966), 215-89.

[9] See my 'Barron Field and the Translation of Romanticism to Colonial Australia', Southerly, 58 (1998), 157-74

[10] Barron Field, First Fruits of Australian Poetry, ed. Richard Edwards (Sydney: Barn on the Hill, 1941). All reference to Field is from this edition

[11] Field's persona there describes the Botany Bay colony as 'a discordant state, / Yet big with virtues (though the flow'ry name / Which Science left it, has become a scorn / And hissing to the nations), if our Great / Be Wise and Good. So fairest Rome became!' (10-14). Qualifications evidently hedge the Roman analogy. As the speaker would have it, a possibility does exist that the settlement might metamorphose into another Rome, but much depends on political discords having been resolved and on the colony's governance coming into the hands of the best and brightest.

[12] 'Australia', in A. D. Hope, Collected Poems 1939-1965 (Sydney: Angus and Robertson, 1966), 13 